\title{
Are Nurses in Oppression? An Approach to Explore the Evidences
}

\author{
Betsy Chakraborty ${ }^{1}$, Anindita Mandal ${ }^{2}$, Suresh K Sharma
}

\author{
${ }^{1}$ Tutor, College of Nursing, All India Institute of Medical Sciences, Rishikesh, Uttarakhand - 249203, India \\ ${ }^{2} \mathrm{PhD}$ Scholar, College of Nursing, All India Institute of Medical Sciences, Rishikesh, Uttarakhand - 249203, India \\ ${ }^{3}$ Professor \& Principal, College of Nursing, All India Institute of Medical Sciences, Jodhpur, Rajasthan - 342005, India
}

DOI: $10.36348 /$ sjnhc.2021.v04i03.005

| Received: 05.03.2021 | Accepted: 23.03.2021 | Published: 25.03.2021

*Corresponding author: Suresh K Sharma

\section{Abstract}

It is well known that nurses are the largest manpower in healthcare delivery system of any country. Though, they spend sleepless nights in caring and curing the sick one but continuously striving for professional honour and dignity what they actually deserve. Instead of getting recognition, respect and reward, this profession face exploitation, struggle for existence, discrimination, humiliation from their own persons and even from medical colleagues. There is a negative portrayal of this professional image as feminine, menial, subservient roles with low intellect, taken for granted and assistance of physician only. The term "Oppression" has been described for nurses who represent powerlessness, submissiveness and domination. Nurse leaders often talks about qualities of self-esteem, assertiveness, accountability, control over practice, self-advocacy and autonomy but in contrary nurses in below hierarchy reported higher levels of dominancy, lack of initiative and fear of retaliation. Negative consequences of oppression resultant decreased workforce performance, dissatisfaction, self-hatred behaviour, submissive aggressive syndrome, horizontal and lateral violence, workplace bullying and poor retention of nurses in the same workplace. Therefore, this article is aimed to pinpoint $\&$ bring insight on those major challenges faced by nurses due to oppression and propose remedial strategies to reshape and uplift this profession as a prestigious one.

Keywords: Oppressed group behaviour, Oppression in nursing, Horizontal violence, Lateral violence, Workplace bullying among nurses, Submissive aggressive syndrome.

Copyright (C) 2021 The Author(s): This is an open-access article distributed under the terms of the Creative Commons Attribution 4.0 International License (CC BY-NC 4.0) which permits unrestricted use, distribution, and reproduction in any medium for non-commercial use provided the original author and source are credited.

\section{INTRODUCTION}

Ashley was often recognized as an early pioneer in identifying powerlessness in nursing since the year 1973 [1, 2] though Roberts (1983) was the first nurse scholar who described about nurses demonstrate oppressed group behaviours and utilized oppression theory to justify it [3]. In common words, "Oppression" considers unfair behaviour, ignoring others' rights, disrespecting their dignity and overlooking of person's statement and opinion [4]. Nurses admit existence of this oppressive behaviour from administrator, seniors and physician; then persist anger; become fury towards oppressive group. But instead of bringing that into light they portray equal range of negative behaviour among own group, one towards another who are in the equal status of the hierarchy, deny their own basic rights and moreover it continues. In between the late 1800 s to early 1900 s, the nursing profession was predominantly meant for women, they used to serve under male physicians with very little pay, their service was not appreciated comparing to other and even physicians were responsible for ruling the nursing education curriculum [5]. Today, after more than 100 years "Nursing" is labelled as a profession where men or women both choose to be nurse for living their livelihood. There is a curriculum from diploma to post-doctorate and nurses are performing various role of specialty care in oncology, nephrology, neurology, psychiatry, anaesthesia, critical care, operation theatre care; nurse educator; clinical instructor; nurse manager; researcher and academicians. But still medical model believed as empowered and shows bright values whereas nurses show dependent-submissive role. Sometimes, nurse leaders try hard to be fitted with the medical and administrative group and adapt the culture of making the fellow feel low for earning the status of power and control and that makes the subordinates more depressive. Gradually, nurses adopt this and abolish their own origin which gives birth to hatred feeling, diminishes self-esteem, start showing passiveaggressive behaviour and later turns into the reason for horizontal and lateral violence among the nursing group 
Betsy Chakraborty et al., Saudi J Nurs Health Care, Mar, 2021; 4(3): 77-83

[5]. Consequences of all those, affects quality patient care, productivity, reputation of organization, poor physical and mental health of nurses. Only nurses can do the needful to prevent it and protect their profession. Support to each other, fights for rights e.g. pay scale, duty hours, leaves, appreciation, promotion, the opportunity for in-service higher education, strong reporting system of any violence and bullying, tough punishment strategies for it, uniform cadre structure, safety measure, basic facilities like food, sanitation, changing room, transportation during night duty, availability of quality personal protective equipment and no discrimination with other members of health care team etc. are the interventions to break the cycle of oppression and make innovations to improve the workplace culture in nursing [6].

\section{METHODS}

Review authors searched PubMed, Medline, Embase, Ovid, Scopus database (last search February 24, 2021) along with some hand search for finding literature eligible for this review. Keywords, Free-text terms and Mesh terms such as "Oppressed group behaviour" AND "Nursing", "Oppression in nursing", “ Horizontal violence" AND “ Nurses", “ Lateral violence" AND "Nursing", "Workplace bullying" AND "Nurses", "Submissive aggressive syndrome" AND "Nursing" etc. has been used. Reviewers searched independently, screened potentially eligible studies by reading the title, abstract and related references to select literature which requires further in a detailed examination. We also reviewed cross-references cited in retrieved articles to identify additional relevant studies. Review authors quoted the area to: (1) determine the prevalence of oppressed group behaviour in nursing; (2) describe the characteristics of the most distressing incidents nurses experience; (3) measure the physical and psychological impact of these events; (4) define the consequences of experiencing such events in organization; and (5) conclude the adequacy of strategies received to manage violence followed by oppression. Overall aim of this review is to make a brief explanation regarding origin, manifestation and effects of oppression among nurses along with summary of evidence, components of models and dimensions along with managerial strategies. Selected articles are also screened in the reference list to find other relevant content.

\section{Need to Trace}

Very recently the suicide news of Bollywood star Sushant Singh Rajput once claims that it happens because of workplace bullying before it's proved. The workplace bullying or horizontal violence is ensued in every profession but never come into news until something extreme happens. Though, there are very few Indian study supports the effect of oppressed group behaviour among nurses but didn't disclose it in primary levels. Still few prominent cases published in newspaper like nurses of M Y Hospital in Indore was on strike in the month of Sept, 2014 on the support of the nurse who was verbally abused by a Doctor on round, who was shouted and told that he would slap her before entire public [7]. In the same year month of July, supervisor was the person who did misbehaviour with an on-duty nurse at Khyala de addiction centre, Punjab [8]. In the year 2020, month of May two news published; one was the news of Sasson General Hospital in Pune where Maharashtra State Nurses Association ask for proper investigation of the death of Assistant Matron Mrs Pawar due to mental harassment by Chief Metron Rajshree Korke regarding long duty hours, no time for lunch, constant posting at COVID 19 ward and lack of adequate PPE [9] and the other one was a Viral Video of Bora Hospital Maharashtra which portrayed verbal abuse for PPE kits towards nurse by Doctor [10]. In the month of June 2020, one of the nurses of Health and Wellness Centre at Balimela in Malkangiri district, Odisha claimed that one of on-duty doctor came ward in intoxicated state, verbally abuse her even pull her hair and does physical abuse [11]. Simultaneously in July 2020, nurses of civil hospital Panchkula protested and beat the psychiatrist who alleged for molesting a nurse on night duty [12]. One of the nurse ventilate in her personal blog about misbehaviour of nurse manager who pointed out her character which is beyond professionalism [13].

Not only that each time nurses need to fight for their basic rights like Post graduate institute of medical education and research, Chandigarh nurses bound to go for strike as they are deprived from risk allowances and non-practice allowances by seventh pay commission [14]. Deprivation is in every aspects like no proper allocation of quarter within the campus, during night shift lack of arrangements for transportation, no proper nurse to patient ratio, multitasking with low remuneration in respect of other discipline, long duty hours without definite break time, no washroom, sitting and resting area, no allowances for postgraduate students, lack of proper promotional guidelines of all cadre of nurses even after in-service education, holding same post of different cadre, lack of proper performance appraisal in all parts of our country. Still need to wait one or two years to be eligible for PostGraduation in different state. Irrespective of all above mentioned problem of this discipline, one burning issue is lack of respect from society though it's a noble profession.

\section{Core concept of oppression}

In the year 1970, Paulo Freire discovered the internalization of Europeans (Dominant group) norms and values in Brazilian (Oppressed group) culture as they were dominated by Europeans for a long time. After close monitoring of Brazilian's oppressed culture, he was motivates to generate "oppression theory" [5]. Oppression theory describe that, over a time submissive group replicate the salient characteristics of dominant 
Betsy Chakraborty et al., Saudi J Nurs Health Care, Mar, 2021; 4(3): 77-83

group, so called bright ones and dismiss their own, which portrayed negatively and subsequently arises low self-esteem. Dominant groups are seen as empowered and majorly hold the capacity of ruling. Sometimes, few leaders within the oppressed group try hard to assimilate oppressor culture for earning the status of dominant group, mostly the power and control they possess but land up in marginal group in between, as oppressor group refuse them because they are unable to completely acquire the feature and they are not fit in their own group in current scenario. The oppressor like behave of the leaders produce hatred feeling among the own group and develop submissive - aggressive syndrome. When they are not able to control own selves, these all repressed emotions and impulses ventilated as negative consequences like horizontal violence, lateral violence, bullying etc. This theory enumerates five prevalent aspects which come one after another i.e. assimilation, marginalization, self-hatred and low self-esteem, submissive-aggressive syndrome and horizontal violence [15]. The horizontal violence is the most dangerous sequel of oppression theory [16]. Freire pointed out that this kind of behaviour is the fruit of uneven social strata. So, the oppressed group can get rid of it through proper education and much needed awareness. Though, symptoms of oppression are detected in nursing profession but very less work has been done on Freire's model [5].

\section{How oppression model affects nursing profession}

People's attitudes and behaviours are chiefly shaped by their position in an organization and the situation in which they discover themselves. Even though the individual's personality and social experiences has some impact on their behaviour but the formal and informal power structures has greater influence on the individual's satisfaction, work effectiveness and health. Effective empowering include (a) access to information, (b) support, (c) access to resources necessary to do the job and (d) opportunity for growth and advancement. Employees who have positive experiences with these structures are empowered and able to accomplish organizational goals $[17,18]$. If so, nurses would be more likely to feel accountable for patient outcomes and become more efficient. But scenario is quite different in developing countries for this profession. Sometimes, written or verbal order and information don't reach up to all. Receiving of minimal appreciation for patient's recovery and claim for near miss or minor error is very common. Administration demands more productive and economic work from them with lower budget and limited resources. Instead of getting support, nurses are fighting for risk allowance, night allowance, childcare leave, conveyance allowance etc.

Opportunities of growth e.g. In-service training, promotion, performance appraisal are minimal in this profession. No proper established reporting system in case of abuse and bulling behaviour. Lack of policy and standardized management force them towards avoid reporting and choosing to be tolerated. Manifestation and Consequences of oppressed group behaviour in nursing has been described in detail in Table-1.

There is presence of two postulations in this profession i.e. oppressed self and oppressed group (discovered by DeMarco et al., [5]. Internalized dominant values are responsible to create horizontal violence among workers. Oppressive culture threats safety needs and emotional demands which finally lead to reduce productivity, poor patient care \& safety (Figure-1).

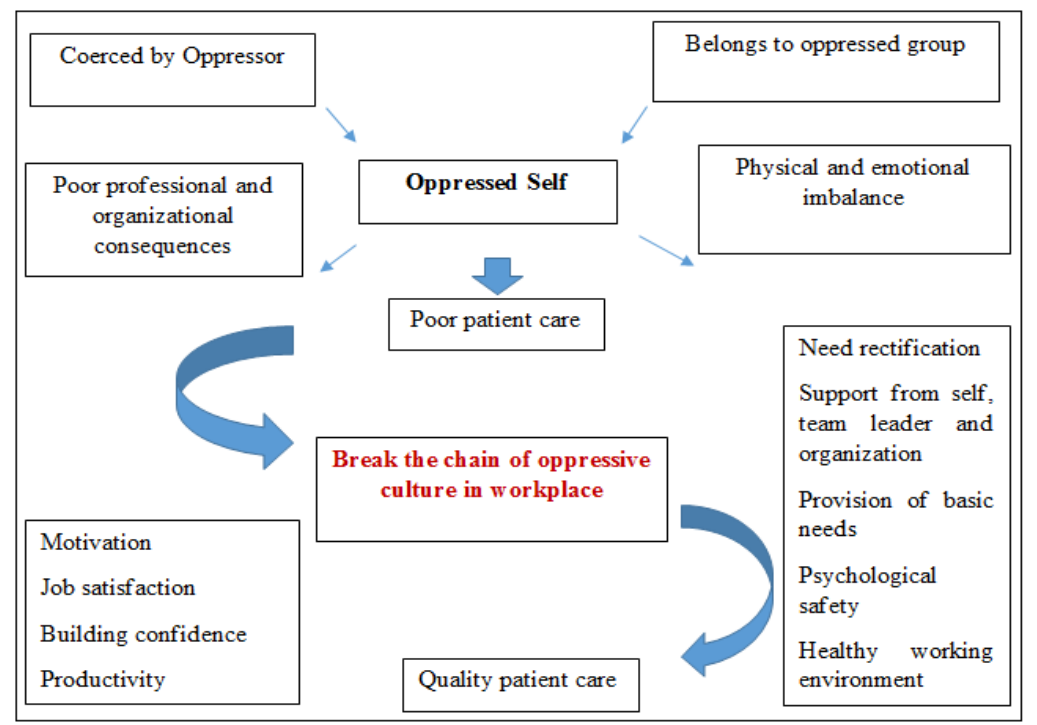

Fig-1: Impact of oppressed behaviour in health care

Only nurses can break the chain through effective communication, positive defences' mechanism, team spirit, fight for self and colleagues and positive contribution in quality of patient care. To deal it nicely, every employee should promote selfvalue, focus on input in health system, find satisfaction 
Betsy Chakraborty et al., Saudi J Nurs Health Care, Mar, 2021; 4(3): 77-83

in patient's recovery, make strong feedback system in organization, communicate politely, treat people as they are, deal conflict or grievances in a firmly manner and take standard action against any disrespectful behaviour or harassment. There is a positive relationship between structural empowerment and the autonomy, control over practice, advocacy for sick one and collaborative nurse- physician relationships [17, 18]. Different strategies have been extracted from the already existing evidence to diminish the forecasted incidence of oppressed group behaviour which can be applied from individual to organizational level. Managerial strategies have been described in detail at (Table-2).

Table-1: Understanding of behavioural manifestation of oppressive behaviour with its consequence [19, 20]

\begin{tabular}{|c|c|c|c|}
\hline Personal & Behaviour & Possible manifestation & Consequences \\
\hline $\begin{array}{l}\text { Oppressor one } \\
\text { Rigid } \\
\text { Powerful figure } \\
\text { Highly influential } \\
\text { More authoritative } \\
\text { High self-esteem } \\
\text { Assertive } \\
\text { Autonomy } \\
\text { Accountability } \\
\text { Control } \\
\text { Try to show mastery }\end{array}$ & $\begin{array}{l}\text { Non- verbal } \\
\text { cues }\end{array}$ & $\begin{array}{l}\text { Eye rolling } \\
\text { Making faces in response to question }\end{array}$ & $\begin{array}{l}\text { Physical impact } \\
\text { Headache } \\
\text { Fatigue or dizziness } \\
\text { Gain or loss weight } \\
\text { Loss of appetite } \\
\text { Pain (abdominal, back) } \\
\text { High BP } \\
\text { Tremor } \\
\text { Sweating } \\
\text { Palpitation } \\
\text { Respiratory problems } \\
\text { Gastrointestinal issues } \\
\text { Sleeping disorder } \\
\text { Worsening of chronic disease }\end{array}$ \\
\hline \multirow[t]{3}{*}{$\begin{array}{l}\text { Oppressed one } \\
\text { Younger } \\
\text { Inexperienced } \\
\text { Less assertive } \\
\text { Lower confidence } \\
\text { Vulnerable } \\
\text { personality } \\
\text { Low self-esteem } \\
\text { Less power \& } \\
\text { autonomy Profoundly } \\
\text { self-hatred feeling }\end{array}$} & $\begin{array}{l}\text { Verbal } \\
\text { remarks }\end{array}$ & $\begin{array}{l}\text { Rude tone \& gesture } \\
\text { Use of abusive language Demeaning } \\
\text { Commenting } \\
\text { Shouting } \\
\text { Patronizing tone of voice } \\
\text { Humiliation } \\
\text { Criticism } \\
\text { Blaming for negative outcomes } \\
\text { Backstabbing } \\
\text { Backbiting } \\
\text { Threat of repercussions for speaking out } \\
\text { Rumours/ Lies spread } \\
\text { Formal complaint processes }\end{array}$ & $\begin{array}{l}\text { Emotional impact } \\
\text { Anxiety } \\
\text { Distress } \\
\text { Frustration } \\
\text { Low self-esteem } \\
\text { Lack of self-confidence } \\
\text { Self-hatred } \\
\text { Neglect } \\
\text { Conflict } \\
\text { Mistrust } \\
\text { Burn-out } \\
\text { Depression }\end{array}$ \\
\hline & $\begin{array}{l}\text { Actions } \\
\text { without } \\
\text { physical harm }\end{array}$ & $\begin{array}{l}\text { Refuse assistance } \\
\text { Do not extend helping hand } \\
\text { Allocate more workload } \\
\text { Withhold information } \\
\text { Exclude from communication } \\
\text { Less importance on the idea of } \\
\text { newcomers } \\
\text { Breach the privacy }\end{array}$ & $\begin{array}{l}\text { Professional impact } \\
\text { Learning blocked } \\
\text { Under valued } \\
\text { Lack of supervision } \\
\text { Lack of support } \\
\text { Increase absenteeism } \\
\text { Lower job satisfaction } \\
\text { Lower productivity and skill } \\
\text { Higher intention to quit } \\
\text { Broken confidence }\end{array}$ \\
\hline & Physical harm & $\begin{array}{l}\text { Banging a fist } \\
\text { Throwing an object } \\
\text { Damage property in victim's presence } \\
\text { Attempt to physical assault Sexual } \\
\text { harassment (either verbally or by making } \\
\text { physical contact which may or may not } \\
\text { require medical attention) }\end{array}$ & $\begin{array}{l}\text { Organizational impact } \\
\text { Poor working environment } \\
\text { Shortage of manpower } \\
\text { Increased staff turnover rate } \\
\text { Increased organisation's } \\
\text { spending in recruiting and } \\
\text { training new nurse }\end{array}$ \\
\hline
\end{tabular}

Table-2: Management strategies of oppression in nursing profession

Individual Level

Own effort of nurses which supports introspection and long-time solution (ANA president Beverly Malone, 1996) [5] 
Betsy Chakraborty et al., Saudi J Nurs Health Care, Mar, 2021; 4(3): 77-83

Self-insight, valued self- worth, early recognition [21], disclosing own stories [22] and self-confrontation [23-25]

Alternation of own and group thought process ${ }^{[26]}$,nurse to nurse information exchange [27], supporting each other, continuous examination to find out in which state they belong [6]

Victims of oppression should never utilize negative coping mechanisms like isolation or self-withdrawal [28].

Bureau of Labor Statistics (2004) sought out empowerment as a solution [29].

\section{Team Level}

Supporting mentorship, encouragement, well coached working environment and proper recognition can be effective (Tinsley \& France; 2004) [30].

Nurturing job satisfaction, sociability, awareness, training and commitment can give positive result (Kuokkanen $\&$ Katajisto; 2003) [31].

Nurse Manager should identify early the symptoms of burn out and oppression to break the repetition of the cycle in workplace culture [6].

Ensure professional attitude in different levels and culture innovative strategies [7] to catch the attention of new beginners.

Providing clear job description, orientation, skill training \& education [32].

Always fight as a team [7].

\section{Organizational Level}

Organization should spread positive vibes in different units and administrator should be strict on inter professional collaboration [33] and sound reporting [34]

Pay scale, recognition, performance appraisal, in-service training and thereafter promotion, risk allowances, night allowance, child care leave, facilities of quarters, transport, night off etc. should be provided to nurse as their rights. Change in nomenclature: Staff nurse to nursing officer. As they are designated should be called by particular one.

Establishment of zero tolerance policy [35], behavioural standard, disciplinary rules \& regulations and proper delegation of responsibility for sound maintenance.

For better surveillance the "Bentham's notion of the panopticon" concept can be utilize in hospital administration. It was a well-designed prison where every prisoner is monitored by a single guard through the use of lighting; the prisoners can see the light not the guard [31]. So, people pretend someone is monitoring them.

Villadsen (2007) [36] revealed the concept of "principles of a psychological contract", where every nursing staff will be accounted for controlling own kind of behaviour.

Other innovative strategy like forming special committees, journal club, awareness program through role play technique and cognitive rehearsal [37].

Victims can file a case against any kind of assaults by a colleagues, patient or relatives. Victim should summit a detailed written report to supervisor.

Government should ensure adequate security and health care and people should utilize the security available.

Fight against non-reporting culture too. In minor cases it may be verbal or written notice but major crime leads from suspension to termination. Top management of grievance and sexual harassment committee is responsible to deal such cases sensitively and surveillance is much needed.

\section{CONCLUSION}

Nurses are the heart of hospital; it is impossible to run health care system without nurses. Therefore, recognition to this profession should be obligatory. Shared assumptions, values, believe are collectively known as organizations culture. Inter professional collaboration among nurses have an impact on work environment as well as, the care delivered and received. Interdisciplinary views, discussions, suggestions, reporting the episodes of incivility in the workplace and educational strategies can be the way of solution for this burning issue.

\section{Acknowledgement: Nil}

\section{Financial Support: Nil}

Conflict of Interest: Authors have no conflict of interest in carrying out this evidence based review.
1. Ashley, J. A. (1973). This I believe: About power in nursing. Nursing Outlook, 21, 637-641.

2. Ashley, J. A. (1976). Hospitals, paternalism, and the role of the nurse. NY, NY: Teachers College Press.

3. Roberts, S. J. (1983). Oppressed group behavior: Implications for nursing. Advances in Nursing Sciences, 21-30.

4. Rooddehghan, Z., ParsaYekta, Z., \& Nasrabadi A. N. (2015). Nurses, the Oppressed Oppressors: A Qualitative Study. Glob J Health Sci, 7(5), 239245. doi:10.5539/gjhs.v7n5p239

5. Matheson, K. L., \& Bobay, K. (2007). Validation of oppressed group behaviors in nursing. Journal of Professional Nursing, 23(4), 226-234.

6. Roberts, S., Demarco, R., \& Griffin, M. (2009). The effect of oppressed group behaviours on the culture of the nursing workplace: a review of the evidence and interventions for change. Journal of Nursing Management, 17, 288-93. 
Betsy Chakraborty et al., Saudi J Nurs Health Care, Mar, 2021; 4(3): 77-83

7. Misbehaviour triggers nurses' strike in Indore hospital. The Hindustan Times. Retrieved Sep 9, 2014, from [https://www.hindustantimes.com/indore/misbeha viour-triggers-nurses-strike-in-indorehospital/story0PU6P6WLf4U4ALYtc4PpRO.html]

8. Ghazali, M. (2014). Nurse accuses Mansa deaddiction centre supervisor of misbehaviour. The Hindustan Times. Retrieved Jul 18, 2014, from [https://m.hindustantimes.com/punjab/nurseaccuses-mansa-de-addiction-centre-superviser-ofmisbehaviour/story-

4poQO7pWCOUZoL4mVKfPiO.html]

9. Abraham, R. (2020). Maharashtra government to probe complaints of nurses' harassment. The Hindu: cities. Retrieved May 02, 2020, from [tps://www.thehindu.com/news/cities/mumbai/ma harashtra-government-to-probe-complaints-ofnurses-harassment/article31485257.ece]

10. Pathare, V. (2020). Doctor abuses nurse for demanding PPE kit; video goes viral. Pune Mirror. Retrieved May 9, 2020, from [https://punemirror.indiatimes.com/pune/civic/doc tor-abuses-nurse-for-demanding-ppe-kit-videogoes-viral/articleshow/75636365.cms]

11. Odisha: Malkangiri Nurse Accuses Doc of Misbehaving In Inebriated State. Ommcom News. Retrieved June 26, 2020, from [https://ommcomnews.com/odisha-news/odishamalkangiri-nurse-accuses-doc-of-misbehaving-ininebriated-state]

12. Bumbroo, S. (2020). Nurses thrash doctor for 'molesting' colleague. The Tribune. Retrieved Dec 15, 2020, from [https://www.tribuneindia.com/news/chandigarh/n urses-thrash-doctor-for-molesting-colleague113089]

13. Helen. (2020). During a meeting, my nurse manager personally attacked my character. Is this a breach of the code of professional conduct? Retrieved Feb 20, 2020, from [ https://www.nurse.com/blog/2012/10/08/during-ameeting-my-nurse-manager-personally-attackedmy-character-is-this-a-breach-of-the-code-ofprofessional-conduct/]

14. Akhzer, A. (2020). PGI nurses' strike: 'Our demands have not been fulfilled by the Seventh Pay Commission'. The Indian Express. Retrieved Feb 27, 2020, from [https://indianexpress.com/article/cities/chandigar $\mathrm{h} /$ pgi-nurses-strike-our-demands-have-not-beenfulfilled-by-the-seventh-pay-commission/]

15. Freire, P. (1970). Pedagogy of the oppressed. New York: Herder and Herder.

16. Purpora, C., Blegen, M. A., \& Stotts, N. A. (2012). Horizontal violence among hospital staff nurses related to oppressed self and oppressed group. Journal of Professional Nursing, 28(5), 306-314
17. Laschinger, H. K. S., Heather, K., \& Wong, C. (1999). Staff nurse empowerment and collective accountability: Effect on perceived productivity and self-rated work effectiveness. Nursing Economics, Retrieved from: http:// web36.epnet.com/citation.asp.

18. Laschinger, H. K. S., Sabiston, J. A., \& Kutscher, L. (1997). Empowerment and staff nurse decision involvement in nursing work environments: Testing Kanter's theory of structural power in organizations. Research in Nursing \& Health, 20, 341-52.

19. Moayed, F.A., Daraiseh, N., Shell, R., \& Salem, S. (2006). Workplace bullying: a systematic review of risk factors and outcomes. Theor Issues Ergon Sci, 7(3), 311-27.

20. Sheridan-Leos, N. (2008). Understanding lateral violence in nursing. Clinical Journal of Oncology Nursing, 12, 399-403.

21. Daiski, I. (2004). Changing nurses disempowering relationship patterns. Journal of Advanced Nursing, 48, 43-50.

22. Skillings, L. N. (1992). Perceptions and feelings of nurses about horizontal violence as an expression of oppressed group behavior - intergroup conflict among nurses. In Thompson, J. L., Allen, D. G., odrigues-Fisher, L. R. Eds., Critique, resistance, and action: Working papers in the politics of nursing. New York: National League for Nursing, 167-185.

23. Griffin, M. (2004). Teaching cognitive rehearsal as a shield for lateral violence: An intervention for newly licensed nurses. Journal of Continuing Education in Nursing, 35, 257-263.

24. Stagg, S. J., Sheridan, D., Jones, R. A., \& Speroni, K. G. (2013). Workplace bullying the effectiveness of a workplace program. Workplace Health and Safety, 61,333-338.

25. Ceravolo, D. J., Schwartz, D. G., Foltz-Ramos, K. M., \& Castner, J. (2012). Strengthening communication to overcome lateral violence. Journal of Nursing Management, 20,599-606.

26. Buerhaus, P. (2000). A nursing shortage like none before. Creative Nursing, 2, 4-7.

27. DeVito, J. A. (2008). Essentials of Human Communication. USA: Pearson

28. Taylor, R. (2016). Nurses' Perceptions of horizontal violence. Global Qualitative Nursing Research. 3, 1-9. doi: $10.1177 / 2333393616641002$

29. Bureau of Labor Statistics. Occupational employment projections. Monthly labour Review, Retrieved Feb, 2004, from: www.bls.gov/emp/emptab21.htm

30. Tinsley, C., \& France, N. E. M. (2004). The trajectory of the registered nurse's exodus from the profession: A phenomenological study of the lived experience of oppression. International Journal of Human Caring, 8, 8-12. 
Betsy Chakraborty et al., Saudi J Nurs Health Care, Mar, 2021; 4(3): 77-83

31. Kuokkanen, K. (2003). Promoting or impeding empowerment? Nurses' assessments of their work environment. Journal of Nursing Administration, 33, 209-215.

32. McKenna, B. G., Smith, N. A., Poole, S. J., \& Coverdale, J. H. (2003). Horizontal violence: experiences of Registered Nurses in their first year of practice. Journal of Advanced Nursing, 42, 90-96.

33. Cox, \& Victoria, M. (2016). Horizontal Violence Effect on Nurse Retention. Graduate Student Projects and Scholarship. Retrieved from: https://digitalcommons.liberty.edu/nurse_grad_pro j_schol/3

34. Johnson, S. L. (2015). Workplace bullying prevention: a critical disclosure analysis. J Adv Nurs, 71, 2384-92. doi:10.1111/jan.12694.
35. Chakraborty, B., \& Mandal, A. (2019). Workplace Violence in Health Care Settings: A Narrative Review. International Journal of Science and Research, 28, 1668-73. Retrieved from: https://www.ijsr.net/search_index_results_paperid. php?id=ART2020707

36. Villadsen, K. (2007). Managing the employee's soul: Foucault applied to modern management technologies. Cadernos EBAPE BR, 5, 1-10. doi.org/10.1590/S1679-39512007000100002.

37. Gillespie, G. L., Grubb, P. L., Brown, K., Boesch, M. C., \& Ulrich, D. (2007). Nurses Eat Their Young: A Novel Bullying Educational Program for Student Nurses. J Nurs Educ Pract, 7, 11-21. doi:10.5430/jnep.v7n7P11. 